Gut, 1963, 4, 136

\title{
Studies of basal and peak acid output with an augmented histamine test
}

\author{
J. H. BARON ${ }^{1}$ \\ From the Institute of Clinical Research, Middlesex Hospital Medical School, London
}

EDITORIAL SYNOPSIS On the basis that the most repeatable measurement of acid output of the stomach is the peak half hour after an augmented dose of histamine, the author suggests a modification of the Kay test, including titration of the gastric juice to neutrality and measurement of the chloride concentration. The aspiration tube was sited fluoroscopically. It is suggested that the 'peak half hour' should be substituted for the period 15-45 minutes after administration of histamine. This modification is supported by the presented data. It should be noted, however, that the titration technique has also been modified.

The ranges of basal and maximum gastric secretion (volume, acidity, acid output, parietal and non-parietal components) in 20 normal males and 20 normal females are presented and analysed for differences of age and sex. Both basal and maximum (histamine stimulated) gastric secretion declined with age, more so in women than in men. 'Maximum' gastric secretion was greater in men than in women, especially in older subjects.

Many gastric function tests measure the response of the stomach to standard artificial stimuli. The continuous collection of gastric juice after an injection of histamine has been used extensively as a measure of acid output (volume $\times$ acidity). Kay (1953) found that increased doses of histamine acid phosphate produced increased quantities of acid up to a dose of $0.04 \mathrm{mg}$. $/ \mathrm{kg}$. after which there was no further increase. This maximum, plateau, response to the augmented dose of histamine has been confirmed in man by Adam, Card, Riddell, Roberts, Strong, and Woolf (1954), and in dogs by Marks, Komarov, and Shay (1960), and is considered to represent the secretion of every parietal cell in the stomach, the parietal cell mass.

Unfortunately different workers using the Kay test have analysed their specimens differently, collected them over different periods of time, and published results which have not taken into account the age, and sometimes even the sex, of their subjects.

In this paper, therefore, I report some of the results in 250 augmented histamine tests performed with a modified Kay technique, assess the repeatability of different parameters of acid secretion, and publish the range of gastric secretion in a normal population, analysed by age and sex, and expressed as volume of juice, acidity, acid output, and postulated parietal and non-parietal components.

'Leverhulme research scholar
METHOD

The patient fasts overnight and in the morning a radio-opaque Ryle's tube, size 12-16 Fr., is passed into the stomach, preferably through the nose. The fasting juice is aspirated and discarded. Under radiological control the position of the tube is adjusted so that the holes near its end lie at the lowermost part of the body of the stomach. The patient then lies on his left side, and spits out his saliva throughout the test. The tube is connected to an electric suction pump, and the stomach continually aspirated at a subatmospheric pressure of $3-5 \mathrm{~cm}$. $\mathrm{Hg}$ for 60 minutes. The flow of juice must be checked continuously, the suction interruped frequently, and if necessary air injected down the tube to dislodge aspirated mucus or mucosa. The volume of gastric juice is measured and the specimen is bottled immediately after filtering through gauze. Mepyramine maleate (Anthisan) $50-100 \mathrm{mg}$. is given intramuscularly and the gastric juice collected for 20 to 30 more minutes and discarded. Histamine acid phosphate $(4 \mathrm{mg} . / \mathrm{ml}$.) in a dose of $0.04 \mathrm{mg}$. $/ \mathrm{kg}$. body weight is injected subcutaneously and specimens are collected $0-15,15-30,30-45$, and 45-60 minutes later, completing the test. For each specimen the $p \mathrm{H}$ is measured with a $p \mathrm{H}$ meter, the titratable acidity by titration with $\mathrm{N} / 10 \mathrm{NaOH}$ to neutrality $(p \mathrm{H} \mathrm{7 \cdot 0-7 \cdot 4})$ with phenol red, and the chloride concentration potentiometrically (Sanderson, 1952).

Initially, in some patients, the basal secretion was measured from 9 p.m. to 9 a.m. This 12-hour nocturnal aspiration was abandoned because it was found uncomfortable by the patient and, as has been shown by Stein, gave results similar to the one-hour morning basal aspirate. 
THE RESULTS OF MODIFICATIONS OF KAY'S ORIGINAL TECHNIQUE

POSITION OF THE TUBE A large-bore radio-opaque Ryle's tube is used, and the position of the tube adjusted under radiological control. Unless this adjustment is done the tip of the tube will be in the body of the stomach in less than half the tests, being otherwise in the fundus or pylorus, the oesophagus, duodenum, or right bronchus (Table I). From all these sites juice can be aspirated and the tube can be sited with accuracy only by fluoroscopy. This fluoroscopy has been stressed by Levin, Kirsner, Palmer, and Butler (1948a and b), James and Pickering (1949), and Card (1952) but is not universal practice either in Britain or the U.S.A.

TIMING OF THE MAXIMUM ACID OUTPUT The gastric juice is collected for an hour after the histamine injection as four 15-minute samples. Physiologically and pharmacologically one is primarily interested in the maximum rate of secretion of the stomach. This can be obtained on an individual as a research procedure by repeated intravenous infusions (Adam et al., 1954), but with the conventional subcutaneous injection secretion rises to a peak and then falls. Kay (1953) found this maximum to occur within the mid-half-hour of secretion, that is, during the period from 15 to 45 minutes after the histamine injection.

The position of the peak quarter-hour of acid secretion has been determined in 250 augmented
TABLE II

TIMING OF MAXIMUM QUARTER-HOUR OF ACID SECRETION IN 250 AUGMENTED HISTAMINE TESTS

\begin{tabular}{cc} 
Period of Maximum Acid Output (min.) & Number of Tests \\
\hline $0-15$ & $27(10 \cdot 8 \%)$ \\
$15-30$ & $96(38 \cdot 4 \%)$ \\
$30-45$ & $68(27 \cdot 2 \%)$ \\
$45-60$ & $41(16 \cdot 4 \%)$ \\
Incomplete fractionation & $18(7.2 \%)$ \\
& $250(100 \cdot 0 \%)$
\end{tabular}

histamine tests (Table II) and found to be most frequent in the second quarter-hour (15-30 minutes). There are unavoidable collection errors in so short a period of time, so that the position of the peak half-hour (two consecutive quarter-hours) of acid secretion was determined in these 250 augmented histamine tests (Table III) and found to be in Kay's mid-half-hour in less than half the tests, although this half-hour formed the largest group. Moreover the timing of this peak secretion may vary from day to day in repeated tests on the same patient, presumably due to the varying rates of diffusion of histamine from the site of injection. The timing of the peak secretion did not appear to be related to the patient's disease.

It therefore seems reasonable to take as the peak acid output that half-hour of secretion which was maximal, whenever it occurred. Recently Marks et al. (1960) have shown in dogs that the maximum acid output in two consecutive peak periods of acid secretion following a subcutaneous injection of

TABLE I

POSITION OF END OF RADIO-OPAQUE TUBE ON FLUOROSCOPY

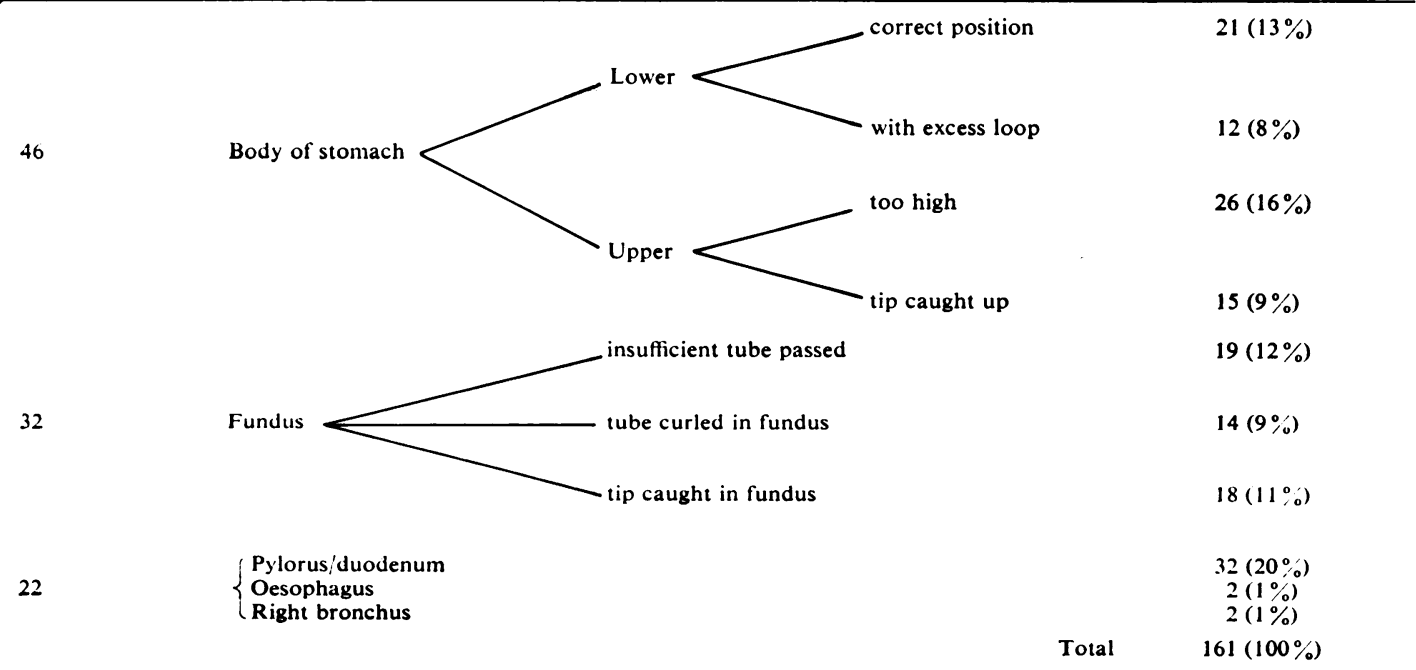

Number of Tests

$21(13 \%)$

$12(8 \%)$

$26(16 \%)$

$5(9 \%$

$14(9 \%)$

$161(100 \%)$ 
TABLE III

TIMING OF MAXIMUM HALF-HOUR OF ACID SECRETION IN 250 AUGMENTED HISTAMINE TESTS

\begin{tabular}{lcccccrr}
$\begin{array}{l}\text { Period of Maximum Acid } \\
\text { Output (min.) }\end{array}$ & Normal & $\begin{array}{c}\text { X-ray } \\
\text { Negative } \\
\text { Dyspepsia }\end{array}$ & $\begin{array}{c}\text { Gastric } \\
\text { Ulcer }\end{array}$ & $\begin{array}{c}\text { Duodenal } \\
\text { Ulcer }\end{array}$ & $\begin{array}{c}\text { Intestinal } \\
\text { Disease }\end{array}$ & Anaemias & All Subjects \\
\hline $0-30$ & 9 & 6 & 3 & 24 & 5 & 4 & $51(20 \cdot 4 \%)$ \\
$15-45$ & 20 & 7 & 26 & 55 & 5 & 2 & $115(46 \cdot 0 \%)$ \\
$30-60$ & 17 & 7 & 18 & 21 & 2 & 3 & $68(27 \cdot 2 \%)$ \\
Incomplete fractionation & 3 & 1 & 0 & 3 & 1 & 8 & $16(6.4 \%)$ \\
Total & 49 & 21 & 47 & 103 & 13 & 17 & $250(100 \cdot 0 \%)$
\end{tabular}

histamine was almost identical with the peak acid output of the stomach determined by successive intravenous infusions of histamine of increasing concentration and was a function of the number of parietal cells in that animal's stomach.

ANALYSIS AND CALCUlations Most workers measure the concentration of 'free acid' by titration

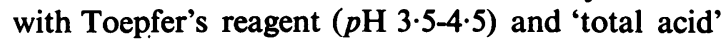
with phenolphthalein $(p \mathrm{H} 8-9)$. It is more reasonable to follow Hollander (1938) and measure titratable acidity by titration to neutrality $(p \mathrm{H} \mathrm{7 \cdot 0-7 \cdot 4)}$ with an indicator such as phenol red. The acidity is then expressed in milliequivalents per litre numerically equal to 'clinical units' and 'ml. N/10 per $100 \mathrm{ml}$. gastric juice'.

A specimen of gastric aspirate is a mixture of the acid secreted by the parietal cells of the stomach, the alkaline juice secreted by the non-parietal cells, and contamination of these gastric components by regurgitation of intestinal, pancreatic, and biliary secretions from below and swallowed saliva from above. Ihre (1938) eliminated most of this contamination by continual separate aspiration of the saliva and duodenal contents. He later showed (Ihre, 1947) that reasonably similar results could be obtained if less stringent precautions against contamination were taken and with just a single tube in the stomach. In the present series patients were asked to spit out excess saliva, and were positioned on the left side in the hope that gastric juice would gravitate to the lower end of the greater curve, and the loss by gastric emptying be lessened.

The two component hypothesis explains the varying composition of gastric juice by the assumption that two components of fixed ionic content are secreted by the stomach in varying volumes. Hollander (1932) postulated that 'the parietal solution is essentially an isotonic solution of hydrochloric acid', and Fisher and Hunt (1950) found that the published data of Ihre (1938) could be best explained by the composition of the two juices (in mEq./1) being:

Acid parietal (P) Cl $170 \mathrm{H} \quad 160$ Kation 10 Alkaline non-parietal (NP) $\mathrm{Cl} 125 \mathrm{HCO}_{3} 45$ Kation 170
From the volume of juice $(\mathrm{V})$ and the amount of acid (A) and chloride $(\mathrm{Cl})$ in that volume Hunt (1950) converted these formulae as follows:

$$
\left\{\begin{array}{l}
\mathrm{Cl}=0.170 \mathrm{P}+0.125 \mathrm{NP} \\
\mathrm{A}=0.160 \mathrm{P}-0.045 \mathrm{NP} \\
\mathrm{P}=4.521 \mathrm{~A}+1.628 \mathrm{Cl} \\
\mathrm{NP}=5.788 \mathrm{Cl}-6.147 \mathrm{~A}
\end{array}\right.
$$

Although this suggested ionic composition of the components is necessarily imprecise (Hunt, 1959) the above formulae are of great value in interpreting gastric secretion and have therefore been used to calculate the volumes of postulated parietal and non-parietal components for each specimen.

If the extragastric contamination of the gastric secretion is minimal, a specimen of gastric juice can be assumed to be a mixture of the two components only, and Thompson and Vane (1953) solved the last two equations above, eliminating the function, chloride, thus:

$$
\begin{aligned}
& \mathrm{P}=\mathrm{V}\left(0.219+4.88 \mathrm{H}^{+}\right) \\
& \mathrm{NP}=\mathrm{V}-\mathrm{P}
\end{aligned}
$$

where $\mathrm{H}^{+}$is the acidity in milliequivalents per $\mathrm{ml}$. This formula makes it possible for the parietal and non-parietal component volumes to be calculated if the chloride concentration was not measured. This calculation is invalid if there is significant extragastric contamination, as has certainly occurred if the chloride concentration is less than $125 \mathrm{mEq} . / 1$.

Table IV shows the peak quarter-hour volume of gastric juice secreted by 10 patients with duodenal ulcer with the highest peak acid output, and the basal hourly volumes of 10 normal men with the lowest basal acid output. The volumes of parietal and non-parietal components were calculated by the formulae of both Hunt (1950) and Thompson and Vane (1953). At high rates of flow the sum of the calculated volumes of parietal and non-parietal components, using Hunt's formula, is within $4 \%$ of the actual volume of the specimen, so that extragastric contamination was slight.

The parietal component volume as calculated by the two formulae differ by only $1 \%$, but the non-parietal component volume calculated by the Thompson and Vane formula is $30 \%$ higher than given by Hunt's formula. 
TABLE IV

CALCULATION OF PARIETAL AND NON-PARIETAL COMPONENT VOLUMES BY FORMULAE OF HUNT (1950) AND THOMPSON AND VANE (1953) AT HIGH AND LOW RATES OF GASTRIC SECRETION

\begin{tabular}{|c|c|c|c|c|c|c|c|c|c|c|}
\hline \multirow[t]{2}{*}{$\begin{array}{l}\text { Volume of } \\
\text { Gastric Juice } \\
\text { (ml.) }\end{array}$} & \multirow[t]{2}{*}{$\begin{array}{l}2 \\
\text { Acidity } \\
(m E q . / l .)\end{array}$} & \multirow[t]{2}{*}{$\begin{array}{l}3 \\
\text { Chloride } \\
(m E q . / l .)\end{array}$} & \multicolumn{2}{|c|}{$\begin{array}{l}\text { Volume of Parietal } \\
\text { Component ( } \mathrm{ml} .) \\
\text { Calculated by Formulae } \\
\text { of }\end{array}$} & \multirow{2}{*}{$\begin{array}{l}6 \\
\text { Difference } \\
\text { Between Two } \\
\text { Calculations } \\
\text { of Parietal } \\
\text { Component } \\
\text { Volume } \\
(5)-(4)\end{array}$} & \multicolumn{2}{|c|}{$\begin{array}{l}\text { Volume of Non-parietal } \\
\text { Component (ml.) } \\
\text { Calculated by Formulae } \\
\text { of }\end{array}$} & \multirow{2}{*}{$\begin{array}{l}9 \\
\text { Difference } \\
\text { Between Two } \\
\text { Calculations } \\
\text { of Non- } \\
\text { parietal } \\
\text { Component } \\
\text { Volume }(\mathrm{ml} .) \\
(8)-(7)\end{array}$} & \multirow{2}{*}{$\begin{array}{l}10 \\
\text { Sum of } \\
\text { Parietal and } \\
\text { Non-parietal } \\
\text { Component } \\
\text { Volumes } \\
\text { (ml.) } \\
\text { (Formulae } \\
\text { of Hunt) } \\
(4)+(7)\end{array}$} & \multirow{2}{*}{$\begin{array}{l}11 \\
\text { Difference of } \\
\text { Sum of } \\
\text { Component } \\
\text { Volumes from } \\
\text { Actual Juice } \\
\text { Volume }(\mathrm{ml} .) \\
(1)-(10)\end{array}$} \\
\hline & & & $\begin{array}{l}4 \\
\text { Hunt }\end{array}$ & $\begin{array}{l}5 \\
\text { Thompson } \\
\text { and Vane }\end{array}$ & & $\begin{array}{l}7 \\
\text { Hunt }\end{array}$ & $\begin{array}{l}8 \\
\text { Thompson } \\
\text { and Vane } \\
(1)-(5)\end{array}$ & & & \\
\hline $\begin{array}{c}\text { Peak quarter-f } \\
150 \\
137 \\
133 \\
131 \\
128 \\
121 \\
114 \\
113 \\
108 \\
100\end{array}$ & $\begin{array}{c}\text { specimens } \\
125 \\
137 \\
111 \\
132 \\
124 \\
135 \\
135 \\
133 \\
135 \\
141\end{array}$ & $\begin{array}{c}10 \text { men wit } \\
150 \\
164 \\
138 \\
165 \\
154 \\
156 \\
166 \\
161 \\
167 \\
159\end{array}$ & $\begin{array}{r}\text { uodena } \\
121 \cdot 4 \\
121 \cdot 5 \\
96 \cdot 9 \\
113 \cdot 4 \\
104 \cdot 0 \\
102 \cdot 7 \\
100 \cdot 4 \\
97 \cdot 4 \\
95 \cdot 3 \\
89 \cdot 6\end{array}$ & $\begin{array}{l}\text { with highest } \\
124 \cdot 4 \\
121 \cdot 7 \\
101 \cdot 2 \\
113 \cdot 1 \\
105 \cdot 5 \\
103 \cdot 8 \\
100 \cdot 1 \\
98 \cdot 1 \\
94 \cdot 8 \\
90 \cdot 7\end{array}$ & $\begin{array}{c}\text { eak acid output } \\
+3.0 \\
+0.5 \\
+4.3 \\
-0.3 \\
+1.5 \\
+1.1 \\
-0.3 \\
+0.7 \\
-0.5 \\
+1.1\end{array}$ & $\begin{array}{r}14 \cdot 9 \\
14 \cdot 8 \\
15 \cdot 5 \\
18 \cdot 7 \\
16 \cdot 3 \\
11 \cdot 7 \\
14 \cdot 7 \\
13 \cdot 1 \\
14 \cdot 5 \\
5 \cdot 2\end{array}$ & $\begin{array}{r}25 \cdot 6 \\
15 \cdot 3 \\
31 \cdot 8 \\
17 \cdot 9 \\
22 \cdot 5 \\
17 \cdot 2 \\
13 \cdot 9 \\
14 \cdot 9 \\
13 \cdot 2 \\
9 \cdot 3\end{array}$ & $\begin{array}{l}+10.7 \\
+0.5 \\
+16.3 \\
+0.8 \\
+6.2 \\
+5.5 \\
-0.8 \\
+1.6 \\
-1.3 \\
+4.1\end{array}$ & \begin{tabular}{r|}
$136 \cdot 3$ \\
$136 \cdot 3$ \\
$112 \cdot 4$ \\
$132 \cdot 1$ \\
$120 \cdot 3$ \\
$114 \cdot 4$ \\
$115 \cdot 1$ \\
$110 \cdot 5$ \\
$109 \cdot 8$ \\
$94 \cdot 8$
\end{tabular} & $\begin{array}{l}+13.7 \\
+\quad 0.7 \\
+20.6 \\
-1.1 \\
+7.7 \\
+6.6 \\
-1.1 \\
+2.5 \\
-1.8 \\
+5.2\end{array}$ \\
\hline Mean 123.5 & & & $104 \cdot 3$ & & $+1 \cdot 1$ & 13.9 & & $+4 \cdot 2$ & & $+5 \cdot 3$ \\
\hline Mean differen & etween tw & alculations & $\%$ of $\mathrm{c}$ & ent volume & $(1 \cdot 1 \%)$ & & & $(30 \cdot 1 \%)$ & & $(4 \cdot 3 \%)$ \\
\hline $\begin{array}{c}\text { Basal hour spe } \\
10 \\
52 \\
14 \\
28 \\
21 \\
30 \\
10 \\
11 \\
43 \\
38\end{array}$ & $\begin{array}{c}\text { nens in the } \\
15 \\
2 \\
18 \\
10 \\
14 \\
14 \\
52 \\
58 \\
15 \\
26\end{array}$ & $\begin{array}{c}\text { normal mer } \\
95 \\
65 \\
122 \\
122 \\
94 \\
96 \\
121 \\
101 \\
74 \\
87\end{array}$ & $\begin{array}{c}\text { th the } \\
2 \cdot 1 \\
6 \cdot 0 \\
4 \cdot 0 \\
6 \cdot 8 \\
4 \cdot 7 \\
6 \cdot 5 \\
4 \cdot 3 \\
4 \cdot 5 \\
7 \cdot 9 \\
9.9\end{array}$ & $\begin{array}{c}\text { basal acid ou } \\
2 \cdot 9 \\
11 \cdot 9 \\
4 \cdot 3 \\
7 \cdot 5 \\
6 \cdot 0 \\
8 \cdot 6 \\
4 \cdot 3 \\
5 \cdot 3 \\
12 \cdot 6 \\
13 \cdot 1\end{array}$ & put $\begin{array}{r} \\
+0.8 \\
+5.9 \\
+0.3 \\
+0.7 \\
+1.3 \\
+2.1 \\
+0.3 \\
+0.8 \\
+4.7 \\
+3.2\end{array}$ & $\begin{array}{r}5 \cdot 2 \\
19 \cdot 1 \\
8 \cdot 2 \\
18 \cdot 0 \\
9 \cdot 8 \\
14 \cdot 3 \\
3 \cdot 8 \\
2 \cdot 7 \\
14 \cdot 8 \\
13 \cdot 0\end{array}$ & $\begin{array}{r}7 \cdot 1 \\
40 \cdot 1 \\
9 \cdot 7 \\
20 \cdot 5 \\
15 \cdot 0 \\
21 \cdot 4 \\
5 \cdot 2 \\
5 \cdot 3 \\
30 \cdot 4 \\
24 \cdot 9\end{array}$ & $\begin{array}{l}+1.9 \\
+21.0 \\
+1.5 \\
+2.5 \\
+5.2 \\
+7.1 \\
+1.4 \\
+2.8 \\
+15.6 \\
+11.9\end{array}$ & $\begin{array}{r}7 \cdot 3 \\
25 \cdot 1 \\
12 \cdot 2 \\
24 \cdot 8 \\
14 \cdot 5 \\
20 \cdot 8 \\
8 \cdot 1 \\
7 \cdot 2 \\
22 \cdot 7 \\
22 \cdot 9\end{array}$ & $\begin{array}{l}+2.7 \\
+26.9 \\
+1.8 \\
+3.2 \\
+6.5 \\
+9.2 \\
+1.9 \\
+3.8 \\
+20.3 \\
+15.1\end{array}$ \\
\hline Mean $25 \cdot 7$ & & & $5 \cdot 7$ & & $+2 \cdot 0$ & 10.9 & & $+7 \cdot 1$ & & $+9 \cdot 1$ \\
\hline \multicolumn{5}{|c|}{ Mean difference between two calculations as $\%$ of component volume } & $(35 \cdot 3 \%)$ & & & $(65 \cdot 2 \%)$ & & $(35.46 \%)$ \\
\hline
\end{tabular}

At very low rates of flow the sum of the parietal and non-parietal components is about one-third less than the actual specimen volume so that extragastric contamination is marked, as could be predicted from the low concentrations of chloride. If the chloride concentration had not been known to be less than $125 \mathrm{mEq}$./1. the formula of Thompson and Vane might have been used and would have exaggerated by one-third and two-thirds respectively the parietal and non-parietal component volumes calculated from the chloride concentration by the Hunt formula.

REPEATABILITY OF THE TEST The repeatability of the various measurements of basal and maximum histamine secretion was assessed on 14 in-patients with duodenal ulcer on whom two to five tests were done. The specimens were analysed by the various methods and the results calculated for the different periods of time which have been suggested in the literature. The measurement of 'free acid' was made only in the basal secretions of eight patients and in the augmented histamine tests in five patients. The formula of Thompson and Vane (1953) was not used for basal secretion because it produced exaggerated values at low rates of flow. Of the 41 tests of basal secretion on 13 patients, three subjects had five tests each; two, four each; two, three each; and in six patients the test was performed twice on each. Of the 31 augmented histamine tests on 10 patients, three subjects had five tests each; two, three tests each; and in five patients the test was performed twice on each. (In one of the 14 patients basal secretion was not measured in the first of his two tests; in four patients the repeatability of maximum secretion could not be assessed because doses of histamine other than $0.04 \mathrm{mg} . / \mathrm{kg}$. were used.)

Table V shows the coefficient of variation (standard deviation/mean $\times 100$ ) of each measurement for each period of time for each of the patient's tests. More weight should be given to the measure of variation in those patients on whom the more tests were done. Table VI shows the weighted means of the coefficient of variation, calculated as the mean of the coefficient of variation of every subject, weighted for the number of tests on that subject. It will be seen that the volume, acidity, and acid 
TABLE V

THE REPEATABILITY OF VARIOUS MEASUREMENTS OF GASTRIC SECRETION ASSESSED BY MEAN COEFFICIENT OF VARIATION (S.D./MEAN $\times 100$ ) OF TESTS ON 14 PATIENTS WITH DUODENAL ULCER

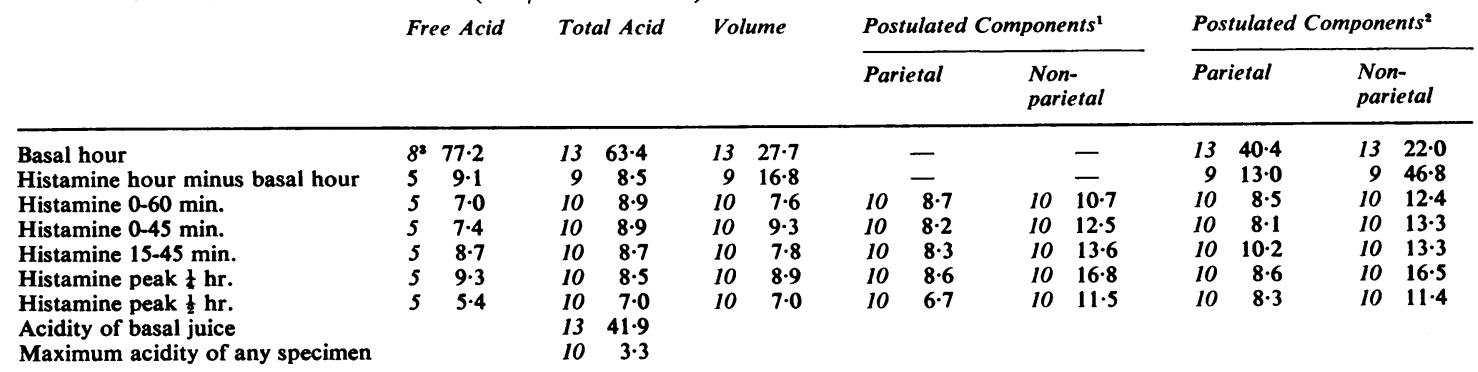

'Calculated from the formula of Thompson and Vane (1953)

${ }^{2}$ Calculated from the formula of Hunt (1950)

${ }^{3}$ Figures in italics are the number of patients on whom that particular measurement was made

TABLE VI

REPEATABILITY OF VARIOUS MEASUREMENTS OF GASTRIC SECRETION ASSESSED BY WEIGHTED MEAN OF THE COEFFICIENT OF VARIATION

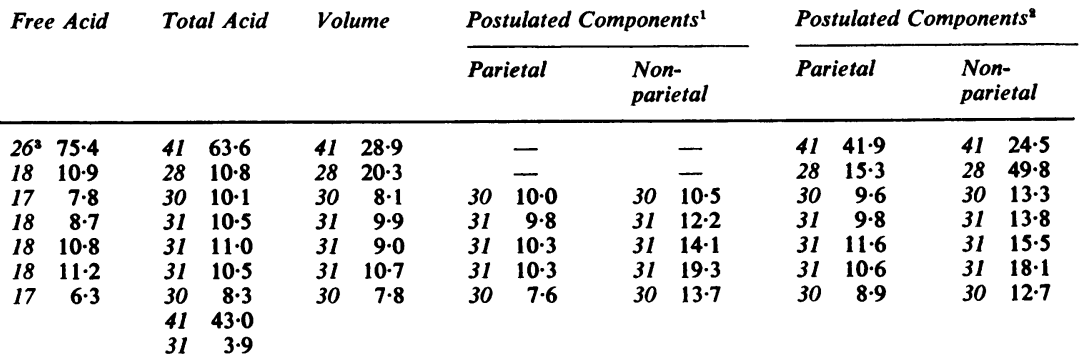

${ }^{1}$ Calculated from the formula of Thompson and Vane (1953)

${ }^{2}$ Calculated from the formula of Hunt (1950)

${ }^{3}$ Figures in italics are the number of tests in which that particular measurement was made.

output of basal secretion vary greatly from day to day. For each maximum output measurement (volume, free, or total acid output) the least variation was found by taking the peak half-hour, rather than the peak quarter-hour, the mid-half-hour, the whole hour, the first three-quarters, or subtracting the basal from the histamine hour. This study of the repeatability of measurements of gastric secretion was done on patients with duodenal ulcer in whom flow rates are high. The repeatability of these measurements may be worse in normal subjects with lower flow rates.

The measurement of acid output in the peak half-hour is here put forward as the best estimate of 'maximum' acid output. For ease of comparison these half-hour outputs have been doubled and the quarter-hour output quadrupled, so that the acid outputs in Tables VII and VIII are expressed in milliequivalents of acid per hour.
THE NORMAL RANGE

It is impossible to obtain a true range of acid output for normal individuals and the usual series of healthy male medical students are obviously unrepresentative of the general population. The 20 men (aged 19-66 years) and the 20 women (aged 19-65 years) were all in-patients (apart from two healthy male doctors). Their occupations and social class were similar to the general hospital in-patient population, and none had suffered from dyspepsia, anaemia, or any disease of the stomach, duodenum, or intestines. Table VII shows the basal and peak histamine secretion expressed as volume of juice, acidity, acid output, and postulated parietal and non-parietal components. Table VIII shows the volume of juice and acid output in the various other periods of time after histamine for the convenience of those who use or wish to use any of these 
TABLE VII

BASAL AND PEAK HISTAMINE SECRETION IN NORMAL SUBJECTS

Men

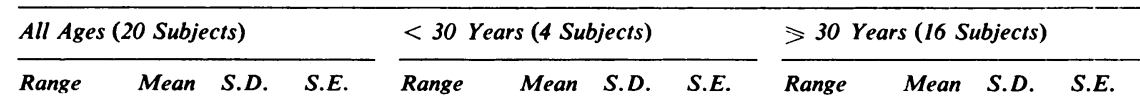

Basal secretion

Volume of juice $(\mathrm{ml} . / \mathrm{hr}$.)

Acidity (mEq. HCl./l.)

$\begin{array}{rrrr}10-93 & 38 \cdot 7 & 23 \cdot 01 & 5 \cdot 15 \\ 0-71 & 29 \cdot 8 & 21 \cdot 68 & 4 \cdot 85\end{array}$

Acid output (mEq.

$\begin{array}{lrrr}0-71 & 29.8 & 21.68 & 4.85 \\ 0.0-6.2 & 1.3 & 1.59 & 0.35\end{array}$

$\begin{array}{llll}2-47 & 12.7 & 11.65 & 2.67\end{array}$

$\begin{array}{llll}25-93 & 50 \cdot 1 & 31 \cdot 22 & 15 \cdot 61\end{array}$

\begin{tabular}{|c|c|}
\hline $25-93$ & \\
\hline
\end{tabular}

$7.02 \quad 0-71$

$0-3$

$\begin{array}{lll}0 \cdot 3-6 \cdot 2 & 2 \cdot 8 & 2 \cdot 18\end{array}$

$1 \cdot 09$
$8 \cdot 37$

2-32

$\begin{array}{lll}35.6 & 19.83 & 4.96\end{array}$

$\begin{array}{lll}28.3 & 22.96 & 5.74\end{array}$

Non-parietal component ${ }^{1}(\mathrm{ml}$./hr.) 4

$\begin{array}{lll}14.8 & 8 \cdot 19 & 1.88\end{array}$

9-31

$17.7 \quad 9.08$

4.54 4-30

$\begin{array}{rrr}1.0 & 1.13 & 0.28\end{array}$

$\begin{array}{lll}10.3 & 8.43 & 2 \cdot 18\end{array}$

$\begin{array}{lll}14.0 & 7.75 & 2.00\end{array}$

Peak histamine secretion

Volume of juice (ml./hr.)

Acidity (mEq. $\mathrm{HCl} / \mathbf{l}$.)

Acid output (mEq. $\mathrm{HCl}$ )

$\begin{array}{llllllllllll}38-406 & 214.9 & 91.48 & 20.46 & 166-406 & 279.0 & 85.33 & 42.67 & 38-360 & 198.9 & 85.76 & 21.44\end{array}$

$\left(2 \times \frac{1}{2}\right.$ hr. peak)

$\begin{array}{rrrr}10-135 & 94.7 & 35.06 & 7.84\end{array}$

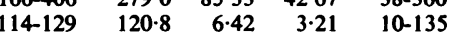

$88.2 \quad 36.26 \quad 9.07$

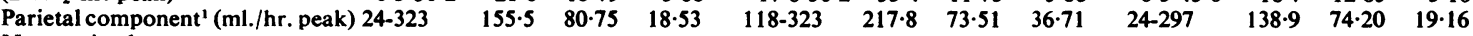

Non-parietal component

(ml./hr. peak)

$50.7 \quad 26.20 \quad 6.01$

$\begin{array}{llll}21-52 & 38.9 & 12.09 & 6.05\end{array}$

$21-141$

$\begin{array}{lll}53.8 & 27.97 & 7 \cdot 22\end{array}$

Women

\begin{tabular}{|c|c|c|c|c|c|c|c|c|c|c|c|c|}
\hline & \multicolumn{4}{|c|}{ All Ages (20 Subjects) } & \multicolumn{4}{|c|}{$<30$ Years (5 Subjects) } & \multicolumn{4}{|c|}{$>30$ Years (15 Subjects) } \\
\hline & Range & Mean & S.D. & S.E. & Range & Mean & S.D. & S.E. & Range & Mean & S.D. & S.E. \\
\hline \multicolumn{13}{|l|}{ Basal secretion } \\
\hline $\begin{array}{l}\text { Volume of juice (ml./hr.) } \\
\text { Acidity (mEq. HCl/l.) } \\
\text { Acid output (mEq. } \mathrm{HCl} / \mathrm{hr} .) \\
\text { Parietal component }{ }^{1}(\mathrm{ml} . / \mathrm{hr} .) \\
\text { Non-parietal component }{ }^{1}(\mathrm{ml} . / \mathrm{hr} .)\end{array}$ & $\begin{array}{l}2-140 \\
0-54 \\
0-6 \cdot 0 \\
1-48 \\
1-38\end{array}$ & $\begin{array}{r}40 \cdot 6 \\
20 \cdot 3 \\
1 \cdot 1 \\
10 \cdot 5 \\
11 \cdot 7\end{array}$ & $\begin{array}{r}38 \cdot 8 \\
18 \cdot 27 \\
1 \cdot 75 \\
13 \cdot 40 \\
9 \cdot 78\end{array}$ & $\begin{array}{l}8 \cdot 68 \\
4 \cdot 09 \\
0 \cdot 39 \\
3 \cdot 00 \\
2 \cdot 19\end{array}$ & $\begin{array}{l}15-140 \\
0-53 \\
0 \cdot 0-6 \cdot 0 \\
2-48 \\
8-38\end{array}$ & $\begin{array}{r}72 \cdot 8 \\
34 \cdot 6 \\
3 \cdot 0 \\
24 \cdot 6 \\
20 \cdot 9\end{array}$ & $\begin{array}{r}53 \cdot 49 \\
18 \cdot 31 \\
2 \cdot 44 \\
18 \cdot 93 \\
13 \cdot 15\end{array}$ & $\begin{array}{r}23 \cdot 92 \\
8 \cdot 19 \\
1 \cdot 09 \\
8 \cdot 47 \\
5 \cdot 88\end{array}$ & $\begin{array}{l}2-90 \\
0-54 \\
0 \cdot 0-2 \cdot 7 \\
1-22 \\
1-20\end{array}$ & $\begin{array}{r}29 \cdot 9 \\
15 \cdot 6 \\
0 \cdot 5 \\
5 \cdot 8 \\
8 \cdot 6\end{array}$ & $\begin{array}{r}24 \cdot 37 \\
15 \cdot 59 \\
0 \cdot 75 \\
5 \cdot 61 \\
5 \cdot 64\end{array}$ & $\begin{array}{l}6.29 \\
4.03 \\
0.19 \\
1.45 \\
1.46\end{array}$ \\
\hline $\begin{array}{l}\text { Peak histamine secretion } \\
\text { Volume of juice (ml./hr.) } \\
\text { Acidity (mEq. } \mathrm{HCl} / 1 .) \\
\text { Acid output (mEq. } \mathrm{HCl} \text { ) }\end{array}$ & $\begin{array}{l}24-304 \\
18-130\end{array}$ & $\begin{array}{r}138 \cdot 2 \\
87 \cdot 2\end{array}$ & $\begin{array}{l}68 \cdot 70 \\
32 \cdot 79\end{array}$ & $\begin{array}{r}15 \cdot 36 \\
7 \cdot 33\end{array}$ & $\begin{array}{l}174-304 \\
109-130\end{array}$ & $\begin{array}{l}225 \cdot 2 \\
119 \cdot 4\end{array}$ & $\begin{array}{c}51 \cdot 4 \\
7 \cdot 36\end{array}$ & $\begin{array}{r}22 \cdot 97 \\
3 \cdot 29\end{array}$ & $\begin{array}{l}24-212 \\
18-117\end{array}$ & $\begin{array}{r}109 \cdot 2 \\
76 \cdot 5\end{array}$ & $\begin{array}{l}45 \cdot 28 \\
30 \cdot 88\end{array}$ & $\begin{array}{r}11.69 \\
7.97\end{array}$ \\
\hline $\begin{array}{l}\left(2 \times \frac{1}{2} \mathrm{hr} . \text { peak }\right) \\
\text { Parietal component }{ }^{1}(\mathrm{ml} . / \mathrm{hr} \text {. peak) } \\
\text { Non-parietal component }{ }^{1}\end{array}$ & $\begin{array}{l}0 \cdot 4-32 \cdot 0 \\
7-208\end{array}$ & $\begin{array}{l}12 \cdot 3 \\
85 \cdot 3\end{array}$ & $\begin{array}{r}8.95 \\
57 \cdot 00\end{array}$ & $\begin{array}{r}2 \cdot 00 \\
12 \cdot 75\end{array}$ & $\begin{array}{l}19 \cdot 2-32 \cdot 0 \\
126-208\end{array}$ & $\begin{array}{r}25 \cdot 3 \\
167 \cdot 2\end{array}$ & $\begin{array}{r}5 \cdot 51 \\
17 \cdot 87\end{array}$ & $\begin{array}{l}2 \cdot 46 \\
7 \cdot 99\end{array}$ & $\begin{array}{l}0.4-15 \cdot 8 \\
7-111\end{array}$ & $\begin{array}{r}8 \cdot 0 \\
58 \cdot 0\end{array}$ & $\begin{array}{r}4 \cdot 72 \\
30 \cdot 36\end{array}$ & $\begin{array}{l}1 \cdot 22 \\
7 \cdot 84\end{array}$ \\
\hline (ml./hr. peak) & $12-50$ & $30 \cdot 9$ & $9 \cdot 86$ & $2 \cdot 21$ & $12-42$ & $38 \cdot 6$ & 6.62 & $2 \cdot 96$ & $32-50$ & $28 \cdot 3$ & $9 \cdot 42$ & $2 \cdot 43$ \\
\hline
\end{tabular}

${ }^{1}$ Calculated from the formula of Hunt (1950).

TABLE VIII

JUICE VOLUME AND ACID OUTPUT IN VARIOUS PERIODS AFTER HISTAMINE

Men

\begin{tabular}{|c|c|c|c|c|c|c|c|c|c|c|c|}
\hline \multicolumn{4}{|c|}{ All Ages (20 Subjects) } & \multicolumn{4}{|c|}{$<30$ Years (4 Subjects) } & \multicolumn{4}{|c|}{$\gg 30$ Years (16 Subjects) } \\
\hline Range & Mean & S.D. & S.E. & Range & Mean & S.D. & S.E. & Range & Mean & S.D. & S.E. \\
\hline $\begin{array}{l}34-339 \\
27-271^{1} \\
38-406^{1} \\
44-406^{1}\end{array}$ & $\begin{array}{l}177 \\
137 \\
203 \\
235\end{array}$ & $\begin{array}{l}73 \cdot 3 \\
52 \cdot 8 \\
97 \cdot 6 \\
98 \cdot 3\end{array}$ & $\begin{array}{l}17 \cdot 3 \\
14 \cdot 8 \\
23 \cdot 0 \\
23 \cdot 2\end{array}$ & $\begin{array}{l}146-339 \\
121-271^{2} \\
166-406^{2} \\
184-406^{2}\end{array}$ & $\begin{array}{l}248 \\
187 \\
279 \\
286\end{array}$ & $\begin{array}{l}71 \cdot 1 \\
62 \cdot 6 \\
98 \cdot 4 \\
91 \cdot 5\end{array}$ & $\begin{array}{l}35 \cdot 5 \\
36 \cdot 1 \\
56 \cdot 8 \\
52 \cdot 8\end{array}$ & $\begin{array}{l}34-278 \\
27-236^{3} \\
38-360^{3} \\
44-372^{3}\end{array}$ & $\begin{array}{l}159 \\
127 \\
188 \\
225\end{array}$ & $\begin{array}{l}68 \cdot 1 \\
57 \cdot 9 \\
90 \cdot 1 \\
96 \cdot 4\end{array}$ & $\begin{array}{l}17 \cdot 0 \\
14 \cdot 9 \\
23 \cdot 3 \\
24 \cdot 9\end{array}$ \\
\hline
\end{tabular}

Acid output (mEq. $\mathrm{HCl})$

0-60 min.

$0 \cdot 1-42 \cdot 1$

$2 \times 15-45$ min. $\quad 0 \cdot 1-50 \cdot 2^{1} \quad 20 \cdot 3$

$4 \times$ peak $15 \mathrm{~min}$. $\quad 0.3-50.2 \quad 23.7$

$\begin{array}{rlll}11 \cdot 94 & 2 \cdot 67 & 14 \cdot 1-42 \cdot 1 & 29 \cdot 4 \\ 9 \cdot 32 & 2 \cdot 20 & 11 \cdot 2 \cdot 33 \cdot 6^{2} & 20 \cdot 6 \\ 14 \cdot 24 & 3 \cdot 36 & 17 \cdot 6-50 \cdot 2^{2} & 32 \cdot 5 \\ 14 \cdot 12 & 3 \cdot 16 & 18 \cdot 0-50 \cdot 2 & 33 \cdot 8\end{array}$

$\begin{array}{rr}10 \cdot 69 & 5 \cdot 35 \\ 9 \cdot 49 & 5 \cdot 48 \\ 13 \cdot 53 & 7 \cdot 81 \\ 11 \cdot 54 & 5 \cdot 77\end{array}$

$0 \cdot 1-33 \cdot 3 \quad 14 \cdot 0$

$0 \cdot 1-29 \cdot 11^{3} \quad 11 \cdot 5$

$0 \cdot 1-45 \cdot 0^{3} \quad 17 \cdot 8$

$10.08 \quad 2.52$

$\begin{array}{llll}14 \cdot 24 & 3 \cdot 36 & 17 \cdot 6-50 \cdot 2^{2} & 32 \cdot 5 \\ 14 \cdot 12 & 3 \cdot 16 & 18 \cdot 0-50 \cdot 2 & 33 \cdot 8\end{array}$

$11.54 \quad 5.77$

$0 \cdot 3-46 \cdot 8 \quad 21 \cdot 1$

$\begin{array}{rr}8.51 & 2 \cdot 20 \\ 13 \cdot 12 & 3.39\end{array}$

$13.56 \quad 3.39$

\begin{tabular}{|c|c|c|c|c|c|c|c|c|c|c|c|c|}
\hline & \multicolumn{12}{|l|}{ Women } \\
\hline & \multicolumn{4}{|c|}{ All Ages (20 Subjects) } & \multicolumn{4}{|c|}{$<30$ Years (5 Subjects) } & \multicolumn{4}{|c|}{$\gg 30$ Years $(15$ Subjects $)$} \\
\hline & Range & Mean & S.D. & S.E. & Range & Mean & S.D. & S.E. & Range & Mean & S.D. & S.E. \\
\hline $\begin{array}{l}\text { Juice volume }(\mathrm{ml} .) \\
0-60 \mathrm{~min} . \\
0-45 \mathrm{~min} . \\
2 \times 15-45 \mathrm{~min} . \\
4 \times \text { peak } 15 \mathrm{~min} .\end{array}$ & $\begin{array}{l}25-241 \\
14-185 \\
12-304 \\
36-328\end{array}$ & $\begin{array}{r}107 \\
83 \\
121 \\
168\end{array}$ & $\begin{array}{l}57 \cdot 7 \\
47 \cdot 4 \\
77 \cdot 5 \\
72 \cdot 0\end{array}$ & $\begin{array}{l}12 \cdot 9 \\
10 \cdot 6 \\
17 \cdot 3 \\
16 \cdot 1\end{array}$ & $\begin{array}{l}122-241 \\
105-185 \\
174-304 \\
188-328\end{array}$ & $\begin{array}{l}188 \\
150 \\
225 \\
242\end{array}$ & $\begin{array}{l}42 \cdot 9 \\
31 \cdot 0 \\
51 \cdot 4 \\
56 \cdot 3\end{array}$ & $\begin{array}{l}19 \cdot 2 \\
13 \cdot 8 \\
23 \cdot 0 \\
25 \cdot 2\end{array}$ & $\begin{array}{c}25-131 \\
14-119 \\
12-212 \\
36-280\end{array}$ & $\begin{array}{r}80 \\
61 \\
86 \\
143\end{array}$ & $\begin{array}{l}30 \cdot 5 \\
26.0 \\
47 \cdot 9 \\
58 \cdot 0\end{array}$ & $\begin{array}{r}7.9 \\
6.7 \\
12.4 \\
15.0\end{array}$ \\
\hline $\begin{array}{l}\text { Acid output }(\mathrm{mEq} . \\
0-60 \mathrm{~min} . \\
0-45 \mathrm{~min} . \\
2 \times 15-45 \mathrm{~min} . \\
4 \times \text { peak } 15 \mathrm{~min} .\end{array}$ & $\begin{array}{l}(C l) \\
0 \cdot 3-28 \cdot 2^{4} \\
0 \cdot 1-20 \cdot 8^{4} \\
0 \cdot 2-31 \cdot 0^{4} \\
0 \cdot 5-34 \cdot 4\end{array}$ & $\begin{array}{r}9 \cdot 4 \\
7 \cdot 3 \\
11 \cdot 7 \\
14 \cdot 4\end{array}$ & $\begin{array}{l}7 \cdot 20 \\
5 \cdot 68 \\
9 \cdot 28 \\
9 \cdot 43\end{array}$ & $\begin{array}{l}1 \cdot 65 \\
1 \cdot 30 \\
2 \cdot 13 \\
2 \cdot 11\end{array}$ & $\begin{array}{l}12 \cdot 6-28 \cdot 2 \\
10 \cdot 5-20 \cdot 8 \\
19 \cdot 2-31 \cdot 0 \\
20 \cdot 0-31 \cdot 6\end{array}$ & $\begin{array}{l}19 \cdot 7 \\
15 \cdot 5 \\
25 \cdot 1 \\
26 \cdot 4\end{array}$ & $\begin{array}{l}5 \cdot 16 \\
7 \cdot 97 \\
5 \cdot 78 \\
5 \cdot 88\end{array}$ & $\begin{array}{l}2 \cdot 31 \\
3 \cdot 56 \\
2 \cdot 36 \\
2 \cdot 63\end{array}$ & $\begin{array}{l}0 \cdot 3-10 \cdot 8^{5} \\
0 \cdot 1-8 \cdot 6^{5} \\
0 \cdot 2-12 \cdot 4^{5} \\
0 \cdot 5-23 \cdot 6\end{array}$ & $\begin{array}{r}5 \cdot 8 \\
4 \cdot 3 \\
7 \cdot 0 \\
10 \cdot 4\end{array}$ & $\begin{array}{l}3 \cdot 16 \\
2 \cdot 54 \\
4 \cdot 54 \\
6 \cdot 54\end{array}$ & $\begin{array}{l}0.84 \\
0.68 \\
1.21 \\
1.69\end{array}$ \\
\hline${ }^{1} 18$ subjects & '3 subjects & & subjec & & $₫ 19$ subjects & & subjec & & & & & \\
\hline
\end{tabular}




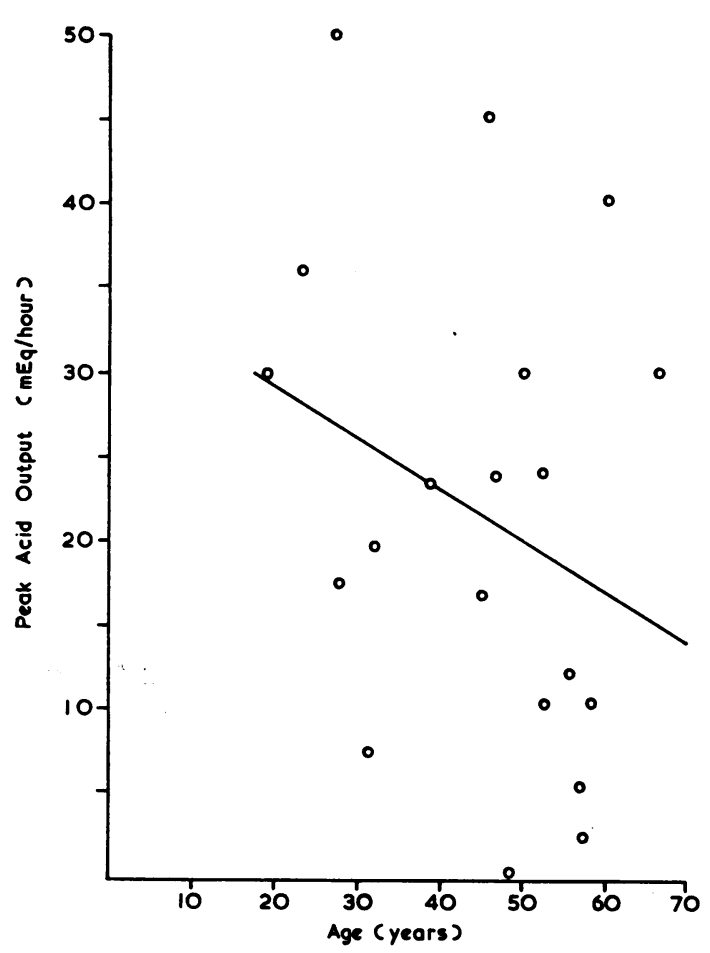

FIG. 1. Peak acid output (P.A.O.) related to age in 20 normal men. P.A.O. $=-0.31$ age $+35.5 ; r=-0.30$; $P>0 \cdot 1$.

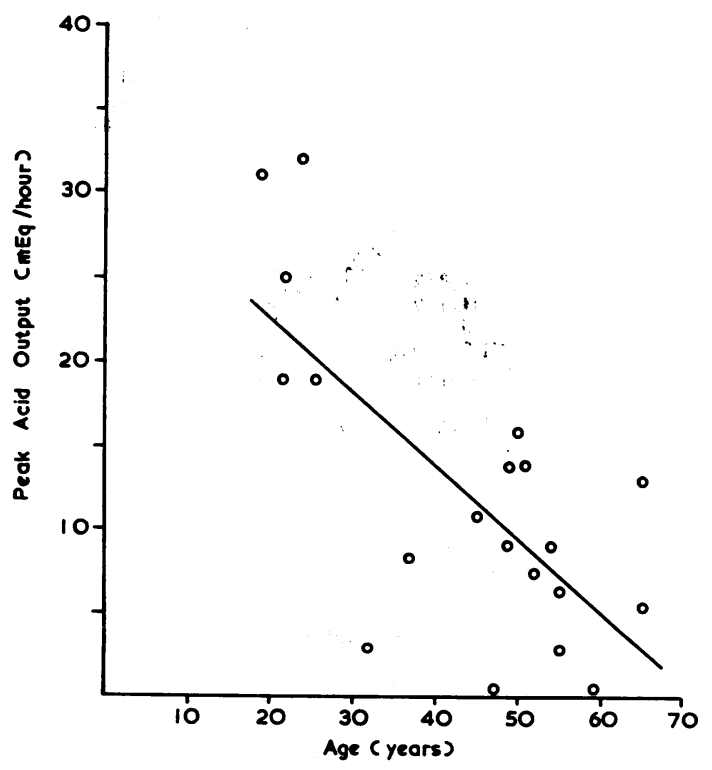

FIG. 2., Peak acid output (P.A.O.) related to age in 20 normal women. P.A.O. $=-0.44$ age +31.8 ; $r=-0.71 ; P<0.001$. measurements. The results are broken down by age and sex, as is essential for any 'normal range'.

EFFECT OF AGE ON GASTRIC SECRETION In the present series both basal and peak acid outputs decrease with increasing age. In men this decrease (Fig. 1) is slight (basal acid output, $r=-0.33$; peak acid output, $r=-0.30$ ) and with this small number, not significantly different from zero $(P>0 \cdot 1)$. If the subjects are arbitrarily divided at age 30 it can be calculated that the basal acid output over 30 years is significantly less $(\mathrm{P}<0.02)$ than in those under 30 years, presumably due to decreased parietal component volume $(0.05<\mathbf{P}<0.1)$, but without significant change in the non-parietal component volume, the acidity, or the volume of the aspirate. For peak acid or parietal component output, the differences between men over and under 30 years is of doubtful significance $(0.05<P<0.1)$.

In women, the decrease with age is much greater. For basal acid output $\mathrm{r}=-0.59, \mathrm{P}<0.01$, and women over 30 secrete at rest less juice $(P<0.05)$, of lower acidity $(P<0.05)$, less acid $(P<0.01)$, and less parietal $(P<0.01)$ and non-parietal $(P<0.02)$ components than women under 30. Figure 2 shows the striking fall in peak acid output in women $(r=-0.71, P<0.001)$, and it will be seen that peak acid output decreases by about $5 \mathrm{mEq}$./hr. per decade. In this small series there was no overlap between the ranges below and above 30 years, and thus highly significant decreases in the peak juice volume $(P<0.001)$, acidity $(P<0.01)$, acid output $(P<0.001)$, and parietal $(P<0.001)$ and non-parietal components $(\mathrm{P}<0.05)$ of women over 30 .

SEX There are no significant differences between the basal secretion of men and women, except for the non-parietal component being less $(P<0.05)$ in women than men over 30 years. At maximum rates of secretion women (all ages) secrete significantly less juice $(P<0.01)$, acid $(P<0.05)$, and parietal $(P<0.01)$ and non-parietal $(P<0.01)$ components than men (all ages), but there is no significant difference between sexes in the maximum acidity achieved. In the subjects under 30 years there is no significant difference between the sexes, so that the sex difference is demonstrated only above that age and is significant $(P<0.01)$ for volume, acid, and component volumes. The sex difference in normal subjects is thus largely due to the falling-off in acid output in older women.

\section{DISCUSSION}

BASAL SECRETION There have been many previous studies in which gastric juice has been continuously 
aspirated over 12 hours at night or one hour in the morning. Unfortunately an individual's spontaneous gastric secretion varies both in volume and acidity from hour to hour and from day to day (Levin, Kirsner, Palmer, and Butler, 1948a), presumably due to nervous and hormonal factors, and also in part to the effects on gastric secretion of the test itself. Sun, Shay, and Ciminera (1955) found that the coefficient of variation of hourly volume and the free and total acid output from hour to hour on the same day was as great as 29,60 and $55 \%$ respectively, and from day to day in the same hour period was as great as 31,65 and $60 \%$ respectively'. The present study confirms that the volume, acidity, and output of acid and parietal and non-parietal components of basal secretion are poorly repeatable measurements of gastric function.

The results in this study are comparable with those in other reports of basal secretion in normal individuals, for example, Ihre (1938), Levin et al. (1948b, 1951), Hunt and Kay (1954), Murray, Erskine, and Fielding (1957), Waddell, Leonsins, and Zuidema (1959), Bruce, Card, Marks, and Sircus (1959), Grossman (1961), and Dotevall (1961).

Since basal acid output declines with age (Levin et al., 1951) the acid output of any series of normal subjects will depend on the age structure of the population tested. The medical students of Ihre (1938), 11 of the 12 women of Levin et al. (1948b), and the 10 non-pregnant women of Murray et al. (1957) were under 30 years of age and the results agree closely with those of the subjects under 30 years of age in the present study. Comparison with other series is difficult because of their different age composition. The results of Levin et al. (1951) are tabulated by decade and tend at all ages to be higher than in the present series.

As in other series men secreted more gastric juice and with a higher acidity than women, but the differences were not statistically significant. The calculated hypothetical parietal and non-parietal components of gastric secretion were secreted in approximately equal quantities under the basal conditions.

MAXIMUM HISTAMINE SECRETION Stimulated gastric secretion is a more repeatable function than basal secretion. The response to a submaximum stimulus varies because of the different numbers of parietal cells stimulated. If Kay's $0.04 \mathrm{mg}$. $/ \mathrm{kg}$. dose of histamine is a maximum stimulation to the parietal cell mass, variations in the response of an individual to repeated tests should be minimal. Repeated tests on successive days did agree within $5 \%$ (Kay, 1953) and the overall coefficient of variation for two or more tests performed on 15 subjects at intervals of up to two years was $9.7 \%$ (Sircus, 1959). The present study confirms the excellent repeatability of measurements of gastric secretion after this augmented dose of histamine. The maximum acidity of the gastric juice was the most repeatable of all the functions tested (weighted mean coefficient of variation $3.9 \%$, , so that the repeatability of measurements of volume and output of acid and parietal component were comparable. For each of these functions the output in the peak half-hour was the most repeatable measurement, and is therefore suggested as the best estimate of maximum output of gastric secretion.

The results in Table VI are expressed as peak outputs, and therefore not directly comparable with those of Kay (1953) and Murray et al. (1957) who collected for the middle half-hour, nor with those of Bruce et al. (1959), of Marks and Shay (1959), and of Dotevall (1961) who collected for 60 minutes after the histamine, a period long enough to include not only peak secretion but also varying periods of basal and submaximum secretion. Table VII shows that, calculated for these other periods of time, the results in this study are similar to those other authors'.

Bloomfield and Keefer (1928a, 1928b), using the submaximum $(0.01 \mathrm{mg} . / \mathrm{kg}$.) dose of histamine, found that both the acidity and volume of gastric secretion declined with age. Polland (1933), who confirmed these decreases for acidity, volume, and acid output, found the decrease with age more marked in men, and therefore published his normal range for each sex by decade. The present study shows that the decline in peak histamine gastric secretion with age in normal subjects (especially women) is more pronounced so that, as with basal secretion, the results for a particular population will depend on its age composition.

All previous authors have shown that normal men have higher maximum acid outputs than women. The present studies show that over the whole range of ages men secrete about one and a half times as much gastric juice and almost twice as much acid. However, such a direct comparison between the sexes ignores the different effects of age on gastric secretion in men and women. In the few young subjects (under 30 years) the sex differences are not significant, and in those over 30 years the differences are accentuated and statistically significant $(\mathbf{P}<$ 0.01). Card (personal communication) suggests that this sex difference can be accounted for by men having a larger lean body mass than women.

The number of subjects in this study was small, and more representative figures are needed of the different functions of gastric secretion in a normal population sufficiently large to provide reliable values by decade and for each sex. 
PARIETAL AND NON-PARIETAL COMPONENT VOLUMES The gastric secretion can be considered as a mixture of parietal and non-parietal components of almost constant composition. 'In principle, therefore, abnormalities of gastric secretion may be based on either too much or too little secretion from the acid-secreting cells, the mucus and bicarbonatesecreting cells, or the pepsin-secreting cells, or any combination of these. If the possible abnormalities of secretion are thought of in this way, it becomes unnecessary to pay any attention to considering the composition of gastric juice, that is mixed secretion, except as a resultant of the varying proportions of components of constant composition' (Hunt, 1961). Calculation of these component volumes can be made by the formula of Thompson and Vane (1953) if only the volume and acidity of the gastric juice are known. Consideration of the data in Table IV suggests the advantages of estimating the chloride concentration of specimens of gastric juice so that a more accurate estimate of the volumes of parietal and non-parietal components can be made by the formula of Hunt (1950).

I wish to thank Dr. G. D. Hadley for his encouragement and advice, and him and the other consultants of the Middlesex Hospital for permission to study their patients, as well as the Clinical Research Committee for facilities in the Institute of Clinical Research. I am grateful to Dr. W. J. Martin for his advice on statistical methods.

\section{REFERENCES}

Adam, H. M., Card, W. I., Riddell, M. J., Roberts, M., Strong, J. A., and Woolf, B. (1954). Dose-response curves for the effect of histamine on gastric acid secretion in man. Brit. J. Pharmacol., 9, 329-334.

Bloomfield, A. L., and Keefer, C. S. (1928a). Gastric acidity: relation to various factors such as age and physical fitness. J. clin. Invest., 5, 285-294.

_ secretion in man. Ibid., 5, 295-301.

Bruce, J., Card, W. I., Marks, I. N., and Sircus, W. (1959). The rationale of selective surgery in the treatment of duodenal ulcer. J. roy. Coll. Surg. Edinb., 4, 85-104.

Card, W. I. (1952). In The Principles and Practice of Medicine, p. 635. Edited by L. S. P. Davidson. Livingstone, Edinburgh and London.

Dotevall, G. (1961). Gastric secretion of acid in diabetes mellitus during basal conditions and after maximal histamine stimulation. Acta med. scand., 170, 59-69.
Fisher, R. B., and Hunt, J. N. (1950). Inorganic components of gastric secretion. J. Physiol., 111, 138-149.

Grossman, M. I. (1961). Physiologic approach to medical management of duodenal ulcer. Amer. J. dig. Dis., N.S. 6, 56-67.

Hollander, F. (1932). Studies in gastric secretion. IV. Variations in the chlorine content of gastric juice and their significance. J. biol. Chem., 97, 585-604.

- (1938). Studies in gastric secretion. VI. A statistical analysis of the neutral chloride-hydrochloric acid relation in gastric juice. Ibid., 125, 161-168.

Hunt, J. N. (1950). An interpretation of histamine and insulin tests in patients with peptic ulceration. Lancet, 2, 397-400.

- and Kay, A. W. (1954). The nature of gastric hypersecretion of acid in patients with duodenal ulcer. Brit. med. J., 2, 1444 1446.

_- (1959). Gastric emptying and secretion in man. Physiol. Rev., 39, 491-533.

- (1961). The clinical use of tests of gastric function. Guy's Hosp. Rep., 110, 237-245.

Ihre, B. J. E. (1938). Human gastric secretion. Acta med. scand., suppl., 95.

- (1947). Studies in gastric secretion with an improved histamine test. Ibid., 196, 322-340.

James, A. H., and Pickering, G. W. (1949). The role of gastric acidity in the pathogenesis of peptic ulcer. Clin. Sci., 8, 181-210.

Kay, A. W. (1953). Effect of large doses of histamine on gastric secretion of $\mathbf{H C l}$. Brit. med. J., 2, 77-80.

Levin, E., Kirsner, J. B., Palmer, W. L., and Butler, C. (1948a). The variability and periodicity of the nocturnal gastric secretion in normal individuals. Gastroenterology, 10, 939-951.

$-,-1,-(1948 b)$. Nocturnal gastric secretion. Studies on normal subjects and on patients with duodenal ulcer. gastric ulcer and gastric carcinoma. Arch. Surg., 56, 345-356.

_ _ _ - (1951). A simple measure of gastric secretion in man: comparison of one-hour basal secretion, histaminesecretion and 12-hour nocturnal gastric secretion. Gastroenterology, 19, 88-98.

Marks, I. N., and Shay, H. (1959). Observations on the pathogenesis of gastric ulcer. Lancet, 1, 1107-1111.

- Komarov, S. A., and Shay, H. (1960). Maximal acid secretory response to histamine and its relation to parietal cell mass in the dog. Amer. J. Physiol., 199, 579-588.

Murray, F. A., Erskine, J. P., and Fielding, J. (1957). Gastric secretion in pregnancy. J. Obstet. Gynaec. Brit. Emp., 64, 373-381.

Polland, W. S. (1933). Histamine test meals. An analysis of 988 consecutive tests. Arch. intern. Med., 51, 903-919.

Sanderson, P. H., (1952). Potentiometric determination of chloride in biological fluids. Biochem. J., 52, 502-505.

Sircus, W. (1959). The application of the 'maximal' histamine test of gastric secretion to problems of peptic ulcer surgery. J. roy. Coll. Surg. Edinb., 4, 153-155.

Stein, I. F., Jr. Comparison of hourly acid output during the night and during a one-hour aspiration of basal secretion. Quoted by Ivy, A. C., Grossman, M. I., and Bachrach, W. H. (1950). Peptic Ulcer, p. 700. Blakiston, Philadelphia.

Sun, D. C. H., Shay, H., and Ciminera, J. L. (1955). Relative effectiveness of anticholinergic drugs on basal gastric secretion. J. Amer. med. Ass., 158, 713-718.

Thompson, J. E., and Vane, J. R. (1953). Gastric secretion induced by histamine and its relationship to the rate of blood flow. J. Physiol. (Lond.), 121, 433-444.

Waddell, W. R., Leonsins, A. J., and Zuidema, G. D. (1959). Gastric secretory and other laboratory studies on two patients with Zollinger-Ellison syndrome. New Engl. J. Med., 260, 56-62. 